\title{
EXTRA-JUDICIAL WAYS OF RESOLVING LEGAL DISPUTES USED IN THE PRACTICE OF BUSINESS ACTIVITY
}

ABRINY Arhouma - Interregional Academy of Personnel Management, Kyiv DOI:10.32782/NP.2019.4.10

У статті проаналізовано способи позасу-
дового вирішення спорів, які застосовуються
як на начіональному так і міждержавному
рівні. Доведено, шо до видів альтернативно-
го вирішення спорів відноситься медіачія,
арбітраж та переговори. Проте в науковій
літературі вживаються й інші визначення
альтернативного вирішення спорів такі як
консіліачія, примирювальна прочедура та
інші. Розглянуте питання про те, чи є си-
стема альтернативного вирішення спорів
одним з виді судочинства і доведено, шо всі
види альтернативного вирішення спорів
не належать до категорї судочинства.
Альтернативні способи вирішення спорів
можуть існувати як на начіональному так
іміжнародному рівні.
Ключовіслова: позасудовіспори, медіачія,
арбітраж, переговори, консіліачія, прими-
рювальна прочедура, судочинство.

The issue of resolving legal disputes is important for the activities of enterprises, institutions and organizations. However, the litigation is not sometimes appropriated because of some circumstances. These circumstances are: the attempts to expedite the trial, corruption in the judicial system, unwillingness to open the circumstances of the case, and a number of others.

In practice, such types of out-of-court dispute resolution are referred to as "mediation," "consolidation," "reconciliation," and "conciliation," "arbitration," and "negotiation." Studies have been conducted in the scientific literature to analyze such types of dispute resolution, but no general analysis of all types of alternative dispute resolution has been made.

The purpose of this article is to compare different types of alternative dispute resolution and to identify their characteristic features

As identified in the scientific literature, alternative dispute resolution is the most commonly used way of resolving issues and disputes between objects of economic activity [1]. In practice, however, it has been proven that there are even closed methods of alternative dispute resolution, which are carried out not only by arbitrators or mediators. It should be noted that there is no single definition of alternative dispute resolution.

The Black's Law Dictionary [2] defines alternative dispute resolution as a procedure for resolving disputes by other means then through litigation, such as mediation and arbitration, which are different from litigation.

The Dictionary of the Swiss Arbitration Association identifies alternative dispute resolution as:

1) non-binding, calm and balanced settlement of the dispute by a third party, not including arbitration (in Europe);

2) any dispute resolution involving a third party, with the exception of litigation, including arbitration (in the USA) [3, p. 6].

There is also a different perspective on the types of alternative dispute resolution.

Alternative dispute resolution is defined as a unifying term that describes methods that parties can use other than litigation, including negotiation, mediation and many types of arbitration 


\section{Адміністративне право}

[2]. However, the issue of comparing the types of alternative dispute resolution has not been sufficiently described in the legal literature.

As it was noted in the scientific literature, there is no single definition of alternative dispute resolution. In Ukraine, the Law of Ukraine "On International Commercial Arbitration" stipulates that arbitration is any arbitration (arbitration tribunal) independently: whether it is specifically designed to considered separate case or whether the arbitral tribunal is a permanent establishment, including the International Commercial Arbitration Tribunal or the Maritime Tribunal arbitration commission at the Chamber of Commerce and Industry of Ukraine [4]. However, there are no definitions of other types of alternative dispute resolution.

In our view, the identification of the types of alternative dispute resolution should begin with mediation analysis. There is also no consensus on the terminological definition of "mediation". The most complete is the definition given in the UNCITRAL Model Law on International Commercial Conciliation. Pursuant to this Law, "conciliation procedure" means a procedure that may be called conciliation, mediation or termed similar content and within which a third party or persons ("mediator") is assisted in seeking a peaceful settlement of a dispute, arose from or in connection with contracts or other legal relationships [5].

In general, there are several definitions of mediation in the scientific literature.

These include their own 'mediation', 'consolidation', 'mediation process', 'reconciliation procedure' and 'conciliation procedure'.

Based on the systematic analysis of international legal acts, as well as the views of scholars on the legal nature of these procedures, the following features of mediation can be distinguished:

1) versatility;

2) voluntariness;

3) the possibility of settling a dispute between two or more persons;

4) the possibility of resolving both existing and potential disputes;

5) the disposition of the parties in determining the rules and procedures;

6) confidentiality;

7) third party independence;

8) equality of parties to the dispute;
9) optionality of mediator's decision;

10) voluntary implementation by the parties of their decision or recommendations of the mediator [6].

In legal science, the legal regulation of mediation is often considered. Legal regulation of mediation in different countries is carried out in different ways. Analyzing the issue of legal regulation of mediation in different countries, Y. Prityka identifies four ways:

1) consists in the integrated legal support of mediation, which is carried out by the adoption of special integrated normative legal acts of the highest legal force (laws);

2) differentiates regulatory and legal support for mediation, which is carried out by determining the mode of mediation in other regulatory legal acts of a procedural nature;

3) there is a lack of regulation of the mediation procedure at the legislative level, but such activity is not prohibited;

4) forbidding legal systems, where mediation between private law entities is officially prohibited by the current legislation, and the resolution of disputes is carried out exclusively by public authorities [7].

Quite often issues of separation of stages of mediation are considered. Different authors have different approaches to determining the stages of mediation. However, the most common method of division into stages involves six stages: initiation, adoption of a case for consideration, search for a solution, conclusion of an agreement, approval and signing of the agreement, execution of the agreement.

According to the broadest classification approach, mediation is divided into sentencing and extrajudicial. Sentencing mediation takes place in the process of court proceedings. However, the options for such mediation are also different.

The first option is when the trial judge proposes that the parties try mediation and may delay the mediation proceedings. Alternatively, when the judge independently conducts mediation, that is, he acts as a mediator and during the trial proposes the parties to conclude a settlement agreement. The third option is when the judge does not accept the case without mediation.

Extra-judicial mediation is done through appropriate methods and with the participation of 
mediators, which provide negotiations and dispute settlers.

Another alternative way to dispute resolution is arbitration. In the scientific literature, the concept of "arbitration" is interpreted in different ways. Some scholars, as a result of the analysis of the arbitration, prove that the arbitration is a matter of private nature, and its task is to resolve the dispute by individuals, who are chosen by the parties as judges [8, p. 307], while others suggest that arbitration actually creates a private judicial system [9, p. 40].

In our view, the question of a private judicial system cannot be raised, because in every state the prerogative of the state is to create a judicial system, and private courts cannot exist, since they are devoid of state support.

An analysis of the nature of arbitration proves that there are different systems of arbitration functioning in each country, but they all share the following:

the autonomy of arbitration against national judicial systems;

not subordination or minimal subordination to the rules of national law;

free will of the parties in the choice of substantive and procedural regulation;

independent determination of the sequence and order of application of arbitration procedures in dispute resolution.

With regard to the classification of types of arbitration, they can be divided into the following:

1. By area of operation: international and domestic or national

2. In terms of time of operation: permanent (institutional) and ad hoc (one-off) arbitration.

3. In order of formation: created by the state, organizations, private.

4. By industry characteristics: commercial, investment, sports, construction and mixed

5. Depending on the subject matter of the dispute: general arbitration, special arbitration and specialized arbitration.

6. Jurisdiction: Arbitration of general jurisdiction, corporate and specialized.

7. Dispute Resolution: Friendly Mediation Arbitrations; arbitration to resolve the dispute in accordance with the rules of law

8. By the degree of binding arbitration - compulsory and voluntary arbitration
The basis for the settlement of the dispute by the arbitrators is the arbitration agreement or the arbitration clause - that is, the agreement of the parties to the arbitration of all or certain disputes that have arisen or may arise between them in connection with any specific legal relationship, regardless of whether they have a contractual relationship character or not.

The parties may determine the place and language of the arbitration, the law applicable to the contract, the qualifying requirements for the arbitrators.

The analysis of the stages of arbitration distinguishes three main ones :

The first stage in the submission of a dispute to arbitration is the question of the jurisdiction of the arbitrator in relation to a particular dispute. In this case, when submitting objections to the parties, each party has the opportunity, in particular, by applying the notion of conformity of the dispute to the arbitral tribunal. The first stage may also determine the composition of the arbitral tribunal and their competence.

The opposite way also be in the case where, through the notion of the suitability of a dispute for arbitration, a party will be able to prove that a particular dispute is subject to arbitration, regardless of whether the other party wishes to apply to a state court.

The next stage is the merits of the case. During this stage, the parties, through their representatives, present their legal positions, provide evidence independently or by order of arbitration. Arbitration is very similar in law and process to a court, but there are some peculiarities, such as the fact that a party may not only require documents from the other party through the arbitration tribunal, but also be obliged to create a document and submit it to the arbitral tribunal. In Ukraine it is possible not provided for by the Code of Civil Procedure of Ukraine. The parties may suspend the arbitration if they can resolve the dispute by way of a concession. Upon familiarization with the legal position, or the position of the party, if the other party has not participated in the case, the arbitration makes a decision.

The third and last is the stage of arbitration is implementation of the decision. The arbitral award may be enforced by the parties voluntarily or by force. The voluntary enforcement of the arbitration award is the most desirable, fully con- 


\section{Адміністративне право}

sistent with the legal nature and purpose of the arbitration as such, and saves the parties' money. In case of refusal of the party against whom the decision was taken from its voluntary execution, it may be enforced by a compulsory order upon the relevant application of the interested party, which is submitted to the state court at the location of the defendant.

In addition to mediation and arbitration, there are other ways of resolving disputes. Some researchers consider negotiation to be the most effective and widespread way of resolving disputes worldwide [10, p. 2]. In science there are different approaches to understanding the legal nature of negotiations. Some scholars refer them to forms of alternative dispute resolution [11, p. 424], others refute this position [12, p. 14]. According to the definition contained in the Law Dictionary [13], negotiation is the process by which a party or group of them resolves a dispute through discussion and coming to an agreement that can be mutually agreed upon. Another dictionary [14] defines negotiation as a discussion aimed at reaching an agreement or settling a dispute. It clearly states that negotiations are a form of alternative dispute resolution.

However, it should be noted that negotiation is not only an independent way of resolving disputes, but also an integral part of all other types of alternative dispute resolution.

In the Interpretive Dictionary, a conversation is defined as " a conversation to exchange views, or to agree on something with someone; communication; discussion for the purpose of clarifying opinions, attitudes of the parties or concluding an agreement »[15, p. 565].

In the scientific literature, the term "negotiation" is found in a broad and narrow sense. For the purposes of our study, we will narrowly consider negotiations as a separate kind of alternative dispute resolution and, at the same time, if the parties failed to reach an agreement, as a component (stage) of other types of alternative dispute resolution.

We can say that negotiation, as a form of alternative dispute resolution, is a process of interaction between the parties to a dispute aimed at reaching certain forms of mutual interest agreement with a view to resolving a legal dispute.

The analysis of the scientific literature makes it possible to distinguish several approaches to understanding the negotiations as a social and legal phenomenon:

1. Negotiations are a process (procedure) of mutual discussion by two or more participants of claims, needs or interests with a view to their elimination or satisfaction in the event of a conflict.

2. Negotiations are a method (method) of conflict management that allows voluntarily and on an equal basis to eliminate existing contradictions while in a maximum way to satisfy each party's own interests and to make decisions on a mutually beneficial basis. Negotiations give the parties an opportunity to find a solution to the dispute themselves.

Negotiations are the direct settlement of disputes by the parties that does not involve the participation of a third party in reaching a mutually beneficial agreement.

Negotiations can be conducted using information and communication technologies - these are electronic negotiations, online negotiations. In terms of participant interaction, electronic negotiations are divided into direct and automatic ones. In direct negotiations, the parties interact with each other using electronic means of communication; in automatic negotiations, systems of electronic dispute settlement are used [16, p. 230].

Negotiations are characterized by all the features of alternative dispute resolution:

a) voluntary and consensual;

b) multiplicity of parties;

c) are used to resolve a dispute between two or more entities;

d) the legal nature of disputes;

(e) universal in nature, that the parties may use negotiations at different levels: individuals, legal entities, international organizations and states;

e) it is possible to refer both to existing and potentially possible disputes for negotiation;

e) control over the parties (the parties have the right to determine the terms and conditions of the negotiations);

g) voluntary implementation of the decision (the parties voluntarily comply with the agreements reached as a result of the negotiations);

g) confidentiality.

The peculiarity of this type of alternative dispute resolution is the absence of a third party. 
However, some scholars consider mediation a special type of negotiation, a feature that is required by a third party. In our view, this approach is wrong, negotiation and mediation are different types of alternative dispute resolution. However, in some countries (such as Brazil), in order to avoid confusion, there are legislative cases where negotiation and mediation are used.

Negotiations usually involve three steps:

beginning,

carrying out,

completion.

The negotiation proposal may be done in writing or verbally form and may take place both before and after the dispute. A reservation on the use of negotiation as a way of resolving potential disputes may also be contained in the text of the agreement between the parties. It is important that the use of negotiation does not restrict the parties to their right to resort to other means of dispute resolution if such negotiations have not been successful.

Negotiation principles are identical for individuals, legal entities and even states. In addition, a number of international instruments contain provisions on the advisability of using negotiation procedures before going to court.

In Art. 28 of the Paris Convention for the Protection of Industrial Property of 20 March 1883 , any dispute between two or more States concerning the interpretation or application of this Convention which is not negotiated may be referred to any of the States before the International Court of Justice. Statements are to be done in accordance with the Statute of the Court, unless the said countries agree on a different means of dispute settlement.

A similar norm is also enshrined in Art. 33 of the Berne Convention for the Protection of Literary and Artistic Works of 24 July 1971 [17]. The preamble to the Agreement on Trade-Related Aspects of Intellectual Property Rights of 15 April 1994 states that its members recognize the rules for ensuring effective and expeditious procedures for the multilateral prevention and settlement of disputes between governments. Thus, the international instruments set the principle of priority of contractual settlement of disputes before the courts [17].

International treaty law provides for a waiting or cooling off period, which usually lasts from
3 to 12 months. During this time, it is believed that the dispute could potentially be resolved through negotiation. It should also be noted that negotiations are often identified by the parties as a mandatory stage of dispute resolution, and in this connection the party seeking to go to court or arbitration must document the negotiation process by sending a notice of negotiation on the issue at issue. If the party acknowledges sending such notification in any form (electronic, written or otherwise) to the opposite party, or its representative (for example, in a dispute against a state - a public authority), the date of receipt of such notification shall be considered as the beginning of negotiations.

Negotiations can result in both dispute resolution and consensus, and a situation where the parties understand that they cannot resolve the dispute through negotiation. In this case, they usually turn to other types of alternative dispute resolution or court.

Negotiations between states can be conducted through correspondence (notes, letters and notifications) or during meetings. The outcome of the negotiations is usually in the form of Memorandum of Understanding (MOU) agreements. At the same time the positions are negotiated and the agenda of the negotiations is developed.

If we analyze the negotiations conducted by Ukraine with other states on territorial issues, an example of such negotiations is the dispute over the Snake Island between Ukraine and Romania. In 1997, the Agreement on Neighborhood and Cooperation Relations between Ukraine and Romania was signed. The diplomatic corps of both states negotiated the delimitation of the continental shelf and exclusive economic zones between the two states. The particular issue was whether Snake Island was an island or a rock, because according to international law, around the rock, the water area could not be considered an exclusive economic zone. Considering that the parties failed to settle their dispute through negotiations, Romania brought the case before the United Nations International Court of Justice on September 16, 2004;

As a result of the dispute with the International Court of Justice, it was decided that Snake Island is indeed Ukrainian, but at the same time the delimitation of the maritime economic zone was carried out according to new coordinates. 
Thus, for example, we can appreciate the importance of negotiating to resolve disputes.

So the analysis of the types of alternative dispute resolution shows that they are successfully applied in both national and international legal practice. In some cases, however, they are much more effective than national courts.

The main features of alternative dispute resolutions are that they resolve disputes much faster than national courts, and in some cases may be less expensive than national courts.

All types of alternative dispute resolution are independent of the state. However, if one of the parties proven to be the defendant refuses to comply with the decision, the other party may apply to a state court to force the other party to enforce it.

All types of alternative dispute resolution are not a separate judicial system, as some researchers have argued, they assist in the resolution of disputes

\section{References}

1. Alternative dispute resolution. URL:http :/www.nolo .com/dictionary/alternative-disputeresolution-(adr)-term. html.

2. Blake S., Browne J., Sime S. A practical approach to alternative dispute resolution. Oxford: Oxford University press, 2014. 595 p.

3. Glossary of Arbitration and ADR Terms and Abbreviations. Geneve: Swiss Arbitration Association, 2009. 48 p.

4. Про міжнародний комерційний арбітраж Закон України від 24 лютого 1994 року N 4002-XII Відомості Верховної Ради України (ВВР), 1994, N 25, ст.198

5. UNCITRAL Model Law on International Commercial Mediation and International Settlement Agreements Resulting from Mediation, 2018 https://uncitral.un.org/en/texts/mediation/ modellaw/commercial_conciliation

6. Аюбченко Я. П. Альтернативні способи вирішення правових спорів: теоретико - правовий аспект / дис. канд юридичн наук 12. 00. 01 «Теорія та історія держави i права;історія політичних і правових учень», Харків 2018, 234 с.

7. Притика Ю. Д. Правовий режим медіації у законодавчих системах зарубіжних країн. Малий $і$ середній бізнес (право, держава, економіка). 2010. № 3-4.

\section{SUMMARY}

The article analyzes the methods of out-ofcourt dispute resolution that apply both nationally and interstate. It has been proven that mediation, arbitration and negotiation are the types of alternative dispute resolution. However, other definitions of alternative dispute resolution, such as consolidation, conciliation, and others, are used in the scientific literature. The issue of whether the alternative dispute resolution system is one type of litigation is considered and it is proved that all types of alternative dispute resolution do not fall into the category of litigation. Alternative dispute resolution may exist nationally and internationally

8. Glasson M. Tissier. Traite theoretique et pratique d'organization judiciare de competence et de procedure civile. 1936. $3221 \mathrm{p}$.

9. Малигіна К. Позасудове врегулювання спорів: огляд існуючих альтернатив. Юридична газета. 2013. № 19/20. С. 40-41.

10. Merrills J. International Dispute Settlement. 4th ed. Cambridge: University Press, 2005. $387 \mathrm{p}$.

11. Lieberman J. K., Henry J.F. Lessons from the Alternative Dispute Resolution Movement. Chicago Law Review. 1986. Vol. 53. № 2.

12. Chatterjee C., Lefcovitch A., Alternative Dispute Resolution: a practical guide, London: Routledge 2008.

13. Legal Dictionary. http://www.legal explanations.com/definitions/negotiation.htm

14. Nolo Legal Dictionary. URL: http://www. nolo.com/dictionary/negotiation- term.html

15.Новий тлумачний словник української мови / украдачі: В. Яременко, О. Сліпушко. Київ: АКОНІТ, 2008. Т. 2. 926 с.

16. Виноградова А. В. Развитие электронного разрешения споров в Европейском Союзе (на примере Великобритании). Сравнительно-правовые аспекты правоотношений гражданского оборота в современном мире: сборник статей Международной научнопрактической конференции памяти доктора юридических наук, профессора В. К. Пучинского. Москва: РУ ДН, 2016. С. 225-231

17. Альтернативное урегулирование хозяйственных споров в сфере интеллектуальной собственности. URL:http ://www.legeas iviata. in. ua/archive/2013/10-2/52. pdf 